\title{
ELECCIONES PRESIDENCIALES EN VENEZUELA
}

El pasado 4 de diciembre, y con los pronósticos cerrados a favor del candidato de Acción Democrática, los ciudadanos venezolanos acudieron a su cita con las urnas para elegir un nuevo presidente de la República. De nuevo, y a pesar de la presentación de doce candidatos, se impuso el modelo bipartidista de «adecos» y «copeyanos».

Jaime Lusinchi, candidato de los «adecos» (miembros y seguidores del Partido, de orientación socialdemócrata, Acción Democrática), centró su campaña electoral en denunciar los errores del Gobierno mediante tres lemas: «Esto no lo aguanta nadie», como expresión de que el Gobierno socialcristiano de Herrera Campins era el peor de la historia política venelozana; «Con Acción Democrática se vive mejor», queriendo recordar que las fases de mayor auge económico se desarrollaron bajo Gobierno socialdemócrata, y «Sí», como expresión de confianza en el candidato «adeco» para sacar de su profunda crisis económica a un país potencialmente muy rico.

Por su parte, Rafael Caldera, candidato de los «copeyanos» (miembros y seguidores del Comité de Organización Política Electoral Independiente, COPEI), basó toda su campaña en el slogan "Vota al Candidato Nacional», e intentó igualmente distanciarse del presidente de la República en ejercicio, para tratar de evitar que el hecho de pertenecer al mismo partido político repercutiera negativamente en los resultados, como, efectivamente, ocurrío.

Precisamente esta bipolarización de la contienda electoral ha producido en la izquierda, también como consecuencia de sus divisiones internas, una situación de anquilosamiento que no le permite avanzar. Así, el Movimiento al Socialismo (MAS) y su candidato a la Presidencia de la República, Petkoff, obtuvo tan sólo un 6,59 por 100 de los sufragios emitidos.

El vencedor indiscutible de estas presidenciales ha sido Jaime Lusinchi, quien consiguió vencer en 19 de los 20 estados que integran la Federación Venezolana, con una mayoría muy cercana a la absoluta, mayoría, por otra parte, que no se habían atrevido a pronosticar los sondeos de opinión más favorables a los «adecos».

El candidato «copeyano», Rafael Caldera, ha sufrido, como miembro del COPEI, el castigo que el elector venezolano dirigía al presidente Herrera Campins. El otro candidato que se ha llevado el resto de los votos ha sido Olabarría, de tenidencia ultraconservadora, quien, sin ni siquiera un partido que respaldase su campaña, ha obtenido el 4 por 100 de los sufragios.

Por último, nos parece interesante reseñar que el sistema de votación en Vene- 
zuela difiere en gran medida del sistema español. En los Colegios electorales de aquella nación hispanoamericana no hay una papeleta por cada partido o coalición de partidos que concurren a las elecciones, sino tan sólo una hoja de grandes dimensiones $(60 \times 40 \mathrm{~cm})$, que recoge todas las candidaturas presidenciales. Con ello se pretende evitar las denuncias por falta de papeletas de cualquier partido. Una vez que el elector ha cogido una de estas papeletas, se introduce en una cabina cerrada y estampa un sello en la candidatura presidencial que desea votar. El voto en Venezuela se configura como un deber y un derecho del ciudadano, deber cuyo cumplimiento se hace exigible para éste hasta el punto de convertirse en voto obligatorio, de tal forma que la cédula electoral timbrada que acredita que el elector ha votado es requisito imprescindible para matricularse en la Universidad, para obtener un cargo público y para sacar el pasaporte.

\section{RESULTADOS DE LAS ELECCIONES PRESIDENCIALES}

\begin{tabular}{|c|c|c|}
\hline Candidatos & Partidos & $\begin{array}{c}\text { Votos } \\
\%\end{array}$ \\
\hline $\begin{array}{l}\text { Jaime Lusinchi } \\
\text { Rafael Caldera } \\
\text { T. Petkoff } \\
\text { Olabarría }\end{array}$ & 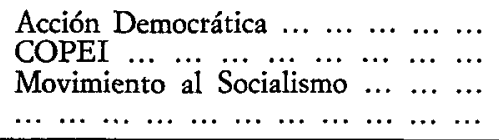 & $\begin{array}{r}52,61 \\
36,80 \\
6,59 \\
4,00\end{array}$ \\
\hline
\end{tabular}

Fuente: El Pais de 6 de diciembre de 1983, ante la imposibilidad de obtener los datos de la Embajada de Venezuela en Madrid.

Pilar Mellado Prado 